\title{
Four concepts of Africa
}

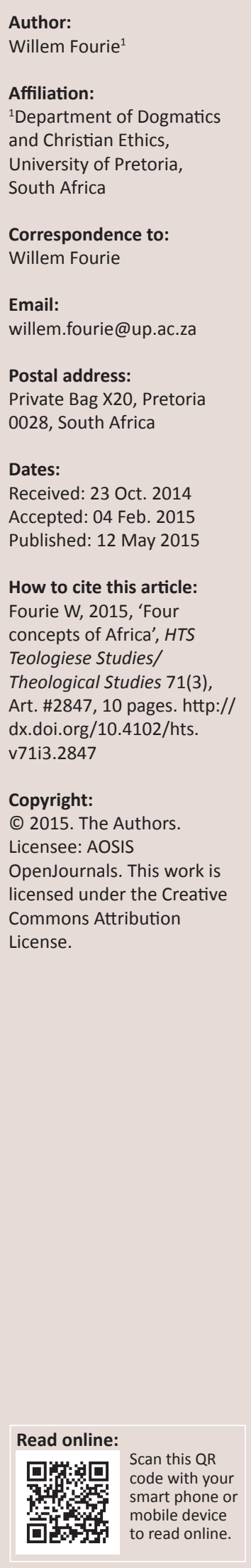

What makes the words 'Africa' and 'African' possible and useful? In this article it is argued that at least four internally coherent concepts of Africa exist, and that none of these concepts are ethically neutral. The article is presented as a contribution to attempts at using the term 'Africa' in self-critical, reflexive and constructive ways. It could therefore be of interest to all researchers, particularly those in the humanities and theology, who locate their research within the context of 'Africa'. It is argued that Africa can be conceived of as a place, a commodity, a condition and an ideal. By drawing on mostly primary sources it is shown that the term 'Africa' only relatively recently came to refer to a continent, that Africa as a place and Africa as a condition in need of betterment formed the foundation for its commodification, and that Africa only very recently became a self-description of the people who live on the continent of Africa. Each of these concepts of Africa is shown to be based on a particular logic with both strengths and weaknesses.

\section{Introduction}

What do we mean when we say 'Africa'?

During the past few centuries references to Africa have become ubiquitous. But what makes 'Africa' and its adjective 'African' possible and useful? Why do we choose to cluster this particular collection of persons and groups together and call it Africa? This question is made more complex by the fact that the act of description is often not a neutral endeavour but also creates that which is described in its image and likeness.

Some might respond intuitively that the existence of the continent of Africa makes it possible to invent a word that represents it as unitary. Africa refers, according to this view, to the persons, groups, institutions and structures found on the continent. I argue that the terms 'Africa', or 'African', are not only geographical designations.

The very existence of the white South African minority group (to which I belong) that continues to benefit from its problematic socio-political history is an indication that there are different and often contradictory concepts of Africa. Many members of this group, for example, choose to refer to themselves as 'Afrikaners', or people from Africa. The language spoken by this group is called Afrikaans. Despite its Germanic roots, its name labels it a language from Africa. It would seem as if there is some concept of Africa that makes it possible for members of this group to associate themselves with Africa. However, this group is especially known for its role in creating and sustaining the societal and political system of apartheid. This system was aimed at separating white South Africans from the rest of the inhabitants of the country. A significant proportion of white South Africans were Afrikaners and initially at least chose to refer to themselves officially as Europeans. The rest of the country's population was referred to as non-Europeans, subdivided into numerous groups. The word 'African' was reserved for black South Africans, even though it is essentially an English translation of the word 'Afrikaner'. There clearly existed - and continues to exist - certain concepts of Africa with which many members of this group choose to associate themselves, and other concepts of Africa with which they find it difficult to associate. As somebody who shares some of the features of people who regard themselves as Afrikaners - such as ethnicity, language, patterns of socio-economic privilege and religion - I am confronted with the fact that the meaning of the notion of 'Africa' is not self-evident or ethically neutral. This is the case both for the concept as a self-description and as a horizon for theoretical reflection.

The aim of this article is twofold: Firstly, to argue that there is not one, but numerous concepts of Africa; and secondly, to argue that none of these concepts are ethically neutral. This article is not an attempt to provide an exhaustive discussion of all the subthemes implied by the concepts of Africa that I identify during the course of my argument. The brevity of the discussion might leave some dissatisfied. Unfortunately the scope of an article in an academic journal does not allow for a more extended discussion. At the same time the argument will fall apart if I choose not to discuss 
all four concepts of Africa identified. For this reason I chose to draw mostly on primary sources, in an illustrative way with the hope that dissatisfied readers will judge the value of this article to lie in my proposal for a differentiated and critical use of the term 'Africa' rather than in the length of the discussion related to the different concepts. In my view, it would in any event be futile - even impossible - to attempt to argue for different concepts of Africa on the basis of all the contexts in which they appear. The contemporary sources that I do use are in no way meant to represent the state of the numerous academic discourses triggered by my argument. Lastly I need to reiterate that I argue for these concepts of Africa knowing full well that they cannot in any way capture the complexity of 'Africa'.

\section{Africa as place}

Even Kwame Nkrumah, a fervent proponent of African political unity, acknowledged the limitations of the use of a merely geographical understanding of Africa, as its inhabitants indeed do not share 'a common race, culture and language'. Writing shortly after the first wave of independence in Africa, he strikingly describes the plurality of the people who live on the continent called Africa:

Some of us are Muslims, some Christians; many believe in traditional, tribal gods. Some of us speak French, some English, some Portuguese, not to mention the millions who speak only one of the hundreds of different African languages. We have acquired cultural differences which affect our outlook and condition our political development. (Nkrumah 1970:132)

Despite the differences amongst people who live in Africa, some might nonetheless argue that the internal coherence of the meaning of Africa should be sought primarily in its designation of the continent of Africa and its inhabitants, as this provides the most neutral and descriptive explanation. In this section I argue that it is indeed possible to conceive of Africa as a place, but that this meaning is neither neutral nor purely descriptive.

The Romans were the first to make Africa a 'place', but in a more restricted sense than we understand Africa today. In 146 BCE the Third Punic War ended with the destruction of Carthage. This was the foundation for the formation of Africa Vetus, Rome's first colony in what is today called North Africa. The conflict between Carthage and Rome initially centred on the control of Sicily. However, during the course of the First and Second Punic Wars, Rome realised that control of the region represented by Carthage would stabilise the southern frontier of the Empire (see Scullard 1980:154). It therefore invested a considerable amount of resources in capturing and largely destroying the city founded by the Phoenicians in 814 BCE. One hundred years later, with the Roman victory at Thapsus, its second colony in this region was established, with the name Africa Nova (Daniels 1987:236). Apart from expressing the power of the expansive Roman Empire and securing the frontiers of the Empire, the African colonies also played a major role in providing for the food supplies of Rome (Le Glay, Voisin \& Le Bohec 2005:174).
The use of the word 'Africa' to name these Roman provinces marks a significant shift from the designations that prevailed before the Roman Empire's expansion. As the Greeks were present in Cyrenaica (present-day north-east Libya) in the 7th century BCE already, a number of Greek texts comment on societies in what is today known as northern Africa. Herodotus's (1890) The histories, written between 450 BCE and $420 \mathrm{BCE}$, is particularly helpful in appreciating the change signified by the Roman nomenclature. Rather than referring to Africa, Herodotus refers to Egypt (Book 1, ch. 1), Libya (Book 1, ch. 46), Ethiopia (Book 2, ch. 22) and to the persons who belong to these communities. His interpretation of the people and their differences is fascinating. He describes Libyans, for example, as people 'disliking the injunction of the religious law that forbade them to eat cows' meat' (Book 2 , ch. 18). Reflecting in another section on the reasons for why Ethiopians and Egyptians, like the 'Phoenicians' and 'Syrians', practice circumcision, he states that the Phoenicians and Syrians are:

[T] he only nations that circumcise, and it is seen that they do just as the Egyptians. But as to the Egyptians and Ethiopians themselves, I cannot say which nation learned it from the other; for it is evidently a very ancient custom. (Herodotus 1890, Book 2, ch. 104)

It is clear that Africa as a name denoting a place was not yet used, and that the Greeks used other words to designate the groups they encountered in what we call Africa. In addition to Libya, Egypt and Ethiopia, the early Greek texts on Africa also refer to Mauretania and the Moors (currently northwest Tunisia and north-east Algeria) and Numidia and the Berbers (currently east Algeria and west Tunisia) (Goodman 1997:276).

What is less clear is the etymology of the word itself. Five explanations are regarded as the most important, namely (1) Leo Africanus's argument that Africa refers to the Greek for a place 'without cold' (aphrike); (2) authors from the Hellenistic era claimed that Africa refers to the descendants of the mythical hero god Afer; (3) the argument that ifri is a Berber word for cave and came to refer to the whole continent; and (4) the argument that Africa is derived from the Phoenician word for dust (Ross 2008:9). Shaw (2014) recently provided evidence for a fifth argument, namely that Africa is derived from the name of the Afri, a small ethnic group that lived in present-day Tunisia and that were the first 'Africans' that the Romans encountered. Afri metonymically came to refer to all of the inhabitants of North Africa (Shaw 2014). The establishment of the Roman army's auxiliary cohort for Africans, the Second Flavian Cohort of Africans, of which the recruitment area was exactly where the Afri resided, supports this thesis (Shaw 2014).

Despite the continuing lack of consensus amongst scholars on the etymology of the word Africa, each of these suggestions, including the most recent by Shaw, share one characteristic. They show that the initial use of the word 'Africa' to designate a place is a result of the Roman Empire's colonisation of North Africa. 
The term 'Africa' remained unstable as a geographical designation for centuries after the demise of the Roman Empire. This was to a large extent a result of changing geopolitics, limited knowledge of the geography of what was to become the continent of Africa as well as the continued use of earlier designations. This is illustrated by the early geographical depictions of Africa. The earliest known printed map of Africa as a continent is that of Antonio Francanzano de Montalbodo, published in 1508 (Betz 2007:78). Its genesis is closely connected to the origins of the Portuguese colonial enterprise and appeared in a book that describes Alvise de Cá da Mosto's two expeditions in the service of the Portuguese king to Cape Verde and Senegal as well as Vasco da Gama's expedition to India, rounding the Cape of Good Hope (Betz 2007:79). The position of the Cape of Good Hope, the width of the continent and major inaccuracies with regard to the Nile, for example, are some of the signs that existing knowledge of Africa was limited.

A map by Sebastian Münster, dating from 1540, became the first readily available map of Africa (Betz 2007:83). Even though this map became famous for its depiction of Monoculi, or cyclopses, in Central Africa, what is particularly important is its use of Ethiopia to designate most of the continent, and Libya and Egypt to denote regions in the north. In addition one finds 'Africa' also referring to a region in the north of the continent. In his (for modern readers) upside-down and (for his contemporaries) influential depiction of Africa in 1556, Leo Africanus also uses Ethiopia to denote Central and Southern Africa, and Libya, Numidia and Egypt to denote most of North Africa (Betz 2007:98). The use of Numidia, Libya, Egypt and also Nubia, for example in Paulo Forlani's map of 1562 (Betz 2007:101), remains constant for most of the early colonial period. As Europeans inhabited more regions, maps of these areas also became more detailed and designations were added. Cefala, in a map from 1570 by Abraham Ortelius, for example (Betz, 2007:118) and Monomotapa, in a 1593 map, for example, by, Cornelis de Jode (Betz, 2007:154), increasingly became generally accepted designations for regions in Southern Africa.

Towards the end of the 17th century the view that Africa denotes a place, that this place is the continent, and that this continent can be divided into regions that show some sort of continuity with the regions the Greeks had already identified was firmly established. Robert Morden, in his depiction of Africa in his book Geography rectified (1680) illustrates this. Apart from the usage of names such as Monomotapa, Ethiopia and Nubia, he provides an interesting - if largely fictional - aside on earlier names for the continent, noting that it was called 'by the Ancients Olympia, Hefperia, Oceania, Coryphe, Ammoni, Ortygia and Ethiopia, by the Ethiopians Alkebu-lam, by the Arabians Ifrichea, by the Indians Befecath, by the Turks Magribon' (Morden 1680:462). He also shows that in the 17th century there was no consensus on the origin of the word 'Africa'. Morden presents five options, varying from Africa as a derivation of the Hebrew word for dust [afer] to locating its origin in Afer, the companion of Hercules. He even posits the view that Africa was the ancient name of Carthage (Morden 1680:462).

Improved maps of Africa and increasing stability in the use of the term 'Africa' were the results of exclusively European activities. The political, economic and socio-cultural developments that were taking place within the societies that would constitute the continent of Africa played a nominal role in the birth of the concept of Africa as a place. In fact, when compared to the history of human settlement on the continent, its designation as Africa is a very late development.

Already around 10000 BCE the presence and proportions of tools, a multiplication of lifestyles, changing strategies of subsistence and changing social and physical environments indicated development and increased diversity in West and Central Africa (Casey 2005:225). Around 2000 BCE speakers of the so-called Bantu languages started to move southwards from the present-day border between Nigeria and Cameroon (Curtin et al. 1995:16). In either a movement that split rather early, before crossing the rainforests of Central Africa, or in a movement that remained unified until after the crossing of the rainforest (cf. e.g. Ehret 2001; Currie et al. 2013) a major dispersal of people took place throughout sub-Saharan Africa. By at least 1000 BCE iron was being smelted in West Africa, with the technology reaching East Africa between 800 BCE and 300 BCE (cf. e.g. Collins \& Burns 2007:162). By 500 copper mining started in Central Africa and long-distance intra-African trade in salt, copper, foodstuffs, fabrics and other commodities had developed (cf. Curtin et al. 1995:26).

Between 1220 and 1290 Mapungubwe was trading gold and ivory in exchange for goods from the coast, which included Chinese porcelain and beads from India. Great Zimbabwe, the successor of Mapungubwe and predecessor of Khami in 1450, continued and consolidated the trade (Huffman 2000; cf. also Collins \& Burns 2007:165-168). At no point in this early history does one find evidence of a conception of Africa as a place that spans the whole of the landmass. Only very few traces of these developments can be found in references to the existing African kingdoms in West, East and Southern Africa (e.g. Sebastian Münster 1540 [Betz 2007:83]), the important trade post at Sofala in East Africa (e.g. Giacomo Gastaldi 1554 [Betz 2007:95]) and Great Zimbabwe (e.g. Giacomo Gastaldi 1564 [Betz 2007:108-109]) on maps and in texts from this time. Africa as a place and a sense of its increasing diversity - as European knowledge increased remained an external perspective on the continent.

When seeking the internal coherence of the concept of Africa in its designation of a place, it is clear that this meaning of Africa is not as stable or neutral as it might seem, and only of limited use. With regard to the stability of the concept I argue that the conception that Africa is a place, and that this place is a continent, are separate developments. One should also acknowledge that for the first few centuries the conception of Africa as a place was not a conscious selfdescription used and appropriated by the inhabitants of the 
continent, but rather a classification or description of a place, conferred by outsiders upon the societies and persons who inhabited it. This challenges the notion that Africa as place is a fundamentally neutral concept of Africa. Concerning its usefulness this meaning of Africa is limited by its inability to account for the vast cultural, linguistic and socio-economic differences between the persons who live in Africa.

\section{Africa as commodity}

In the previous section I argued that the conception of Africa as a place is of limited use and is not as neutral as it seems to be. In this section I argue that a second internally coherent meaning makes the use of the concept of Africa possible: Africa as commodity. A commodity in this sense is understood as an entity without self-reflexivity that is claimed and exchanged to create value for actors external to the entity. I use the imperialist phase of the colonial era as paradigmatic illustration of the commodification of Africa. This by no means implies that this concept of Africa is restricted to the colonial era. The aim of this section is to argue that Africa has an internal coherence and also as a commodity used to create value for actors external to it. The discussion will be limited to Africa as political and economic commodity.

The imperialist phase of the colonial era institutionalised the concept of Africa as commodity, claimed and exchanged to create political and economic value. The establishment of a French protectorate over Tunisia in 1881 can be regarded as the advent of this phase of the colonial era. It was followed a year later by the British occupation of Egypt in 1882 (Wesseling 1996:11-34, 34-51). Whereas the previous phases of colonialism were 'pragmatic' and 'haphazard', this phase was 'driven by ideology from the metropolitan centre and concerned with the assertion and expansion of state power' (Young 2009:16). Africa and its constitutive societies became commodities that created political value in Europe by producing 'national prestige and closed markets in the international arena through conquest' (Young 2009:31). This is also the period during which more countries entered the political market, notably Germany. Against the background of the start of Germany's imperialist phase, and the competition between a half-hearted coalition between King Leopold II of Belgium and France and an unpopular Anglo-Portuguese coalition, Otto von Bismarck convened the now infamous Berlin Conference (Wesseling 1996:99104). Between April 1884 and the conclusion of the Berlin Conference the following year, Germany acquired SouthWest Africa and Togo, with the acquisition of German East Africa taking place the day after the conference (Wesseling 1996:111).

The Berlin Conference, held as separate meetings between November 1884 and February 1885, is the symbol of the political commodification of Africa. The implications of the structure of this meeting are staggering: External actors came together to coordinate their intended activities on an entire continent in order to maximise political and economic value for themselves. The structure of the coordination, the ways in which it was to be executed and the type of value that was to be created made it impossible for any person or group in Africa to grasp or resist their commodification. One of the most powerful tools in this process was the concept of Africa itself. The notion that Africa is an entity made the coordination of colonial intentions possible, and made the prevention of its commodification from within Africa impossible, as most of the persons and groups on the continent at that time could not know that they were part of an entity called Africa.

The primary aim of the Berlin Conference was to settle disputes on different claims to the Congo, and to lay the foundation for settling European claims to African land and trade in the future. Already before the conference many treaties were entered into between representatives from colonial powers and persons identified as local leaders. These treaties were seen as ways to formalise European claims to land and to enable trade, which often included the creation of exclusive markets. The nature and content of many of these treaties were often absurd. The Franco-Italian explorer Pietro Savorgnan di Brazzá, for example, signed the famous BrazzaMakoko treaty with the King of the Bateke in 1880 in which the King ceded all his land to the French in return for their protection. This treaty later played an important role in the eventual establishment of the Congo Free State of Leopold II of Belgium, even though Brazzá was 'a naval officer on leave', 'travelling in the service of a French committee which was a branch of an international philanthropic organisation' tasked 'to set up two scientific stations' (Wesseling 1996:95). An extant British treaty, used in different forms between 1884 and 1892 in more than 50 cases (Worger, Clark \& Alpers 2010:235) provides an indication of the one-sidedness of many of these treaties. In this treaty (Hertslet 1894:476), the 'King and Chief' cede 'for ever, the whole of [their] territory', transferring 'full jurisdiction of every kind' and assigning 'for ever, the sole right to mine in any portion of [their] territory'. The colonial company is recognised as the authorised Government of [their] territories.' The motivation for signing this treaty is described as 'bettering the condition' of the 'country and people' of the respective local leader (Hertslet 1894:476) and protection from the colonial company as far as 'practical' (Hertslet 1894:477).

This does not mean that the partition of Africa took place during this conference. In his initial invitation extended to Paris, London and Lisbon, Bismarck proposed only three agenda points, namely achieving consensus on freedom of trade in the basin and the mouth of the Congo River, freedom of navigation on the Congo and Niger rivers, and principles that need to be observed when taking possession of new territories on the coast of Africa (Wesseling 1996:114). The 'scramble for Africa' (cf. Pakenham 2001) was only to start in all earnest after this conference, with the partitioning of the continent concluded two decades later. It is therefore informative that in the German-speaking world the conference is referred to as the Congo Conference (Kongokonferenz) (cf. e.g. Königk 1938). 
However, heightened imperialist ambitions in Europe, the increased need for natural resources and new markets, coupled with a belief that Africa holds untold riches and inhabitants in need of civilisation led to this conference acquiring major significance (cf. e.g. Reid 2009). The General Act of the Berlin Conference therefore goes beyond the initial agenda in many respects. It declares, for example, that its signatories have the right to claim more land along the coast of Africa, with only one provision: That they should notify the other signatories in order to 'enable them, if need be, to make good any claims of their own' (Berlin Conference on West Africa 1885:ch. VI, Article 34).

In order to enable signatories to 'make good' their respective claims on territories in Africa, the years following the Berlin Conference saw the proliferation of bilateral treaties between European countries. Due to limited knowledge of the interior of Africa, numerous treaties were viewed as 'skeleton treaties', pending improved knowledge of the areas included by these treaties. If there was no prospect of gaining adequate knowledge of the area covered by the treaty, degrees of latitude and longitude were used to fix its borders (Wesseling 1996:128). Even though all African borders were therefore not equally arbitrary, all of the borders were the result of coordinated activities embedded in a relatively integrated network of political and economic needs and wants of external actors. The result is that, after the partitioning of Africa was completed in 1914, 15 of what were to become African states were landlocked (more than in any other region), 177 African cultural and ethnic groups were partitioned over borders (Englebert, Tarango \& Carter 2002:1095-1096), with 80\% of the borders of African countries following latitudinal or longitudinal lines (Alesina, Easterly \& Matuszeski 2011:246).

For the sake of conceptual clarity one could propose a distinction between Africa as political commodity and Africa as economic commodity. However, in reality these two dimensions of the commodification of Africa were mutually dependent. The General Act of the Berlin Conference, ${ }^{1}$ for example, starts with the declaration that the trade of all of its signatories 'shall enjoy complete freedom in all the regions forming the basin of the Congo and its outlets' (Berlin Conference 1885:ch. I, Article 1) and all imports will be 'free from import and transit dues' (Berlin Conference 1885:ch. I, Article 4). The Congo River shall be 'free for the merchant ships' (Berlin Conference 1885:ch. IV, Article 13) and a Commission established at the Berlin Conference was to be responsible for deciding 'what works are necessary to assure the navigability of the Congo in accordance with the needs of international trade' (Berlin Conference 1885:ch. IV, Article 20). Towards the end of the Act the relation between the political and economic commodification of Africa is made explicit. The signatories recognise:

$[T]$ he establishment of authority in the regions occupied by them on the coasts of the African continent sufficient to protect

1.The most accessible versions of the General Act of the Berlin Conference (1885) can be found online. See Bibliography for references to English, German and French versions. existing rights, and ... freedom of trade and of transit ... (Berlin Conference 1885:ch. VI, Article 35)

Africa as a commodity with the potential to create both economic and political value, of course, precedes the imperialist phase of colonialism. It is generally acknowledged that colonial activities in Africa up to the mid-1800s were in fact economically driven (Young 2009:17), even if colonies were used as points of coordination for economic activities that took place elsewhere. A helpful illustration is the case of the Dutch East India Company. Dutch merchants founded the corporation in 1602, with a charter from the Dutch StatesGeneral giving it 'a trade monopoly and administrative powers from the Cape of Good Hope eastward' (Curtin et al. 1995:257). This does not imply that between the 1600s and early 1900s Africa was the most important political or economic commodity of the European states. Indeed, exports from Africa and its markets had a relatively small impact on European economies (for a classic economic view, see O'Brien 1982; Reid 2009:136). Of greater importance for the concept itself and the systematisation presented here, is the disproportionate and at times unintended effects the commodification had on Africa.

Despite the access that this concept provides to grasping the enduring effects of colonialism and the pathways it opens to continued critique of the standards in terms of which Africa is measured, its very usefulness can also be a source of its limitations. Such a concept of Africa runs the risk of portraying Africans as helpless victims and ironically perpetuating their commodification. The people and groups that inhabit the continent are more than the sum of their commodification. In addition, this concept runs the risk of disregarding the differentiated effects of colonialism.

\section{Africa as condition}

The General Act of the Berlin Conference places the proposed political and economic commodification of Africa within an ideological framework. The document is permeated by the belief that the African condition is one in need of betterment until it is 'civilised', and that the signatories of the Act have the responsibility to better this condition by means of trade and political development. The Preamble states the intention of the Act, namely 'to regulate the conditions most favourable to the development of trade and civilisation in certain regions of Africa', and thus ensuring all its signatories 'the advantages of free navigation on the two chief rivers of Africa flowing into the Atlantic Ocean.' According to this logic, the 'guarantee of security to trade and industry' will support the 'development of civilization' (Berlin Conference 1885:ch., Article 10). This is why they commit themselves 'to watch[ing] over the preservation of the native tribes, and to care for the improvement of the conditions of their moral and material well-being' in order to '[bring] home to them the blessings of civilization' (Berlin Conference 1885:ch. I, Article 6).

In this section I argue that the concept Africa is also internally coherent as depicting a condition. This concept is 
closely related to the previous two concepts and expresses a further explanation for the possibility of conceiving and treating the continent as a commodity. Africa as a condition has internal coherence as it is diagnosed as lacking in terms of an externally defined standard and treated by uncritically setting this standard as the remedy. In this section the application of the notion 'civilised' to Africa is identified as crude illustration of this logic, and the discussion is then expanded to contemporary descriptions of Africa.

In 1871 the British anthropologist Edward Tylor published what was to become a foundational work for understanding people in Africa, Primitive cultures: Researches into the development of mythology, philosophy, religion, language, art, and custom ([1871] 1920). He regards the 'savage tribes' as being at 'an early stage of the human race at large', or in a 'primitive condition' (Tylor [1871] 1920:21). His argument is based on the assumption that 'civilisation' exists 'among mankind in different degrees' (Tylor [1871] 1920:26). According to Tylor, at least five principles should be applied when assessing the level of civilisation, namely the 'absence or presence, high or low development' of the 'industrial arts' (which includes metalworking, agriculture and architecture), the 'extent' of scientific knowledge, the 'definiteness' of moral principles, the 'condition' of religious beliefs and ceremonies and the 'degree' of social and political organisation (Tylor [1871] 1920:26-27). He regards the level of civilisation the lowest amongst what he calls savages and the highest amongst the 'civilised' nations of Europe and America. Between savagery and civilisation he places barbarism and semi-civilisation (Tylor [1871] 1920:39). In his references to Africa, it is clear that he regards most of the people he encountered as either 'savage' or 'barbaric', and certainly in need of 'civilisation' (cf. e.g. Tylor [1871] 1920:163).

Even though the concept civilisation itself is thought to be a product of the Third French Republic, the first written evidence of the word dates to 1766 and denotes 'the essence of French achievements compared to the uncivilized world of savages, slaves and barbarians' (Conklin 1997:14, 11-37). 'Civilisation' was a unitary concept, based on the assumption that 'there existed a single universal human civilization capable of winning over from savagery all peoples and nations' (Conklin 1997:15). In 1870 it was institutionalised as official political doctrine in the form of France's mission civilisatrice. This understanding of civilisation expressed an overly optimistic conception of the stability and the content of European 'civilisation' and its ability to address the primitive condition of those found especially in Africa. Tylor is therefore convinced that ' $i t]$ may safely be presumed that no [civilised] people, unless the face of nature is changed, will relapse into their original barbarism' (Tylor [1871] 1920:34) as '[ $d]$ egeneration probably operates more actively in the lower than in the higher culture' (Tylor [1871] 1920:46). This leads him to the conclusion that 'barbarous nations and savage hordes, with their less knowledge and scantier appliances, would seem particularly exposed to degrading influences' (Tylor [1871] 1920:46).
These - and other - texts make it plausible to argue that the concept of Africa had, and in revised form continues to have, internal coherence as a condition. This condition was conceived as a primitive stage of what can develop into a version of European civilisation, and European civilisation is understood in an idealised and uncritical manner. Or, put differently: This condition was quite simply the absence of European civilisation and therefore primitive.

Few authors can match the clarity with which the French anthropologist Lucien Lévy-Bruhl uncritically utilises this standard of civilisation and diagnoses its absence. In 1910 he published Les fonctions mentales dans les sociétés inférieures, translated in 1926 into English as How natives think ([1926] 1985). To be sure, he received criticism from especially anthropologists in English-speaking countries. However, the continuity of much of his thought with ideas that were in vogue makes it an important illustration of the internal coherence of a conception of Africa as a condition. His uncritical use of a European self-interpretation of civilisation as standard is undeniable. In his treatment of 'primitives' perceptions', for example, he concludes 'primitives perceive nothing in the same way as we do', as they cannot separate 'mystic properties' in the way an object is presented 'to their minds' (Lévy-Bruhl [1926] 1985:46). According to him, 'primitives' have a 'prelogical mentality', which means it would be futile to compare 'the discursive processes of prelogical mentality and those of our thought, or to look for any correspondence between the two'. In fact, there exists 'no a priori reason for admitting that the same process is used by both' (Lévy-Bruhl [1926] 1985:105).

This concept of Africa is clearly ethically problematic. When Africa is conceptualised as a condition, when this condition is conceptualised as the absence of a standard defined and exemplified elsewhere, and when the achievement of this standard is understood as remedy for the African condition, then critical reflection on the limits of this standard is easily abandoned or even disabled. This can lead to misjudgement, self-deception, the imposition of unattainable or irrelevant goals and sheer brutality.

This is illustrated in an unintentionally ironic statement by Lévy-Bruhl. His wholly uncritical and idealised understanding of European civilisation leads him to the conclusion that it is especially the 'primitives' who run the risk of relying on 'preconnections, preperceptions, and pre-conclusions' to the extent that their 'logical activity' is disabled (Lévy-Bruhl [1926] 1985:110). For him, the legitimacy of European civilisation is beyond critical reflection, which disabled him from asking what the weaknesses and limits of this idea of civilisation were. He was not able to consider the possibility that alternative forms of civilisation could exist, also in Africa, and that an application of the institutions, aims and practices found in European civilisation might even have a negative effect on certain societies.

In 1959 Léopold Senghor already, prophetically, highlighted this danger by critiquing African leaders of the day. $\mathrm{He}$ 
noticed that the leaders of 'African peoples who have come to self-government and independence' showed a 'lack of awareness ... and ... contempt for African values' (Senghor 1979:77). Real freedom is not simply 'political freedom' or 'freedom of bodies' but indeed the 'freedom of minds' (Senghor 1979:77). This type of freedom will not be achieved if institutions are imported 'without selection'. These views were supported by Sékou Touré, who similarly argued that: 'Subjective interpretations are at the root of one of the profound misconceptions that prevent a true understanding of Africa's problems and the concerns and activities of her peoples' (Touré 1963:108). We would be mistaken, however, to assume that Senghor and Touré therefore proposed and that I am implying - disposing of the institutions from outside Africa. They much rather propagated the critical and reflective use of these institutions. It is in no way the intention to 'stop [these institutions] at the customs posts' (Senghor 1979:78). The ideal is much rather the analysis of 'their forms and their spirit' in order to see 'what should be retained and how this can be made to take root in the realities of Africa' (Senghor 1979:78). The usefulness of this concept of Africa might just lie, paradoxically, in the possibility it creates to reflect critically on the standards in terms of which the state of Africa is measured and the goals that are set for the development of the continent.

\section{Africa as ideal}

The proposals for concepts of Africa that I have presented thus far have one characteristic in common. They were initially used as an external perspective on the people and groups who reside in what is today called Africa. This has changed, as the different concepts of Africa came to be used and applied not only by people from outside Africa. It is no longer possible to say that only persons from outside Africa view it as a place, or that only persons from outside Africa utilise it as a commodity to create political and economic value for themselves, or that only people from outside Africa use the concept to denote a condition that needs to be improved.

The fourth concept of Africa that I argue has internal coherence in the sense that it reclaims subjectivity and reinterprets selected elements of the socio-cultural, economic and political resources in Africa as a representative ideal. It marks the shift from using the concept of Africa to denote the other to using it to denote the self. It signifies the reclaiming of subjectivity by reinterpreting and thus attempting to redeem a word that was used to objectify and in many cases degrade. Its structure resembles that of a synecdoche, as the part - and indeed specific interpretations of it - is used to represent the whole. The result is that the adjective 'African' rather than the substantive 'Africa' is often used, in order to qualify the part that is to be representative of an ultimately idealised whole. In this section I argue that this concept of Africa is internally coherent with reference to the notions of reclamation, reinterpretation and representation. I argue that 'Africa' or 'African' can be used to denote representative ideals, which are based on the reclamation and requisite reinterpretation of African socio-cultural resources. In accordance with the previous sections I attempt to draw in an illustrative manner mostly on primary sources and examples.

One of the earliest examples of the reclamation of African subjectivity and the reinterpretation of African sociocultural resources can be found in the work of Senghor. His response to Lévy-Bruhl's How natives think is one of the most spectacular illustrations of this endeavour. According to Lévy-Bruhl ([1926] 1985), 'the mental activity' of the 'primitives',

is too little differentiated for it to be possible to consider ideas or images of objects by themselves apart from the emotions and passions which evoke these ideas or are evoked. (p. 36)

Europeans find it difficult 'by any effort of imagination' to understand the way 'primitives' think, because their 'mental activity is more differentiated' and they are 'more accustomed to analyzing its functions' (Lévy-Bruhl [1926] 1985:36). Senghor responds not by refuting LévyBruhl's argument, but by reinterpreting it. In fact, Senghor deconstructs Lévy-Bruhl's view by seemingly affirming it and using it to construct a caricature of 'Europeans'. He then uses the deconstruction to explain the reasons for the European colonial enterprise, highlights its effects and affirms the validity of the socio-cultural resources in Africa (Senghor 1979:29ff.).

Senghor starts his response in a quasi-anthropological style, mocking the quasi-anthropology of Lévy-Bruhl: 'Let us consider the first European as he faces an object...' (Senghor 1979:29). The African ceases to be that which is investigated, but becomes the investigator. But within the space of a few sentences Senghor dissolves the distinction between investigation and interpretation, and then goes further by dissolving the distinction between interpretation as a merely intellectual exercise and interpretation as an activity with concrete effects:

[The European] first distinguishes the object from himself. He keeps it at a distance. He freezes it out of time and, in a way, out of space. He fixes it, he kills it. (Senghor 1979:29)

It is done with the very same 'precision instruments' and the resulting 'pitiless factual analysis' that Lévy-Bruhl ([1926] 1985) disparagingly views the 'primitive' unable of understanding. Senghor then proceeds by meticulously tracing the results of this enterprise. Senghor echoes and reframes Kant - the pre-eminent European - to make this point: '[The European] makes a means of it' (Senghor 1979:29). He expands the distinction between means and ends by drawing an even more radical conclusion. Making something a means to an end, is 'a centripetal movement', which ultimately leads to the assimilation of the other. The European 'destroys it by devouring it'. This 'process of devouring' is, according to Senghor, the true meaning of what is called 'humanizing nature' or 'domesticating nature' (Senghor 1979:29). 
Senghor's response to Lévy-Bruhl ([1926] 1985) - whom he seems to treat as representative for a school of theorists culminates in his explanation of why this 'humanisation', or civilising mission, cannot disable African subjectivity, and why it is possible to reclaim and reinterpret the concept of Africa:

But ... what they don't take into account ... is that life cannot be domesticated, nor especially can God who is the source of all life, in whom all life shares. (Senghor 1979:29)

In another text he develops this line of thinking further by developing a notion of assimilation that negates the French colonial project and affirms the reclamation and reinterpretation of being African (Senghor 1979:33ff.). To be African means to abandon the ' $\mathrm{I}$ ' in order to sympathise and identify with the 'thou'. An African 'dies to himself to be reborn in the other, and therefore 'does not assimilate' but 'is assimilated' (Senghor 1979:32). Realising that he might seem to come dangerously close to providing arguments in favour of colonial attempts at assimilating Africans, he qualifies the reinterpretation of assimilation:

[An African] does not kill the other life, he strengthens his own life through it. He lives with the Other in a communal life, lives in symbiosis: he is born-with and thereby knows the Other. (Senghor 1979:32)

This leads to an African reformulation of Descartes's 'cogito ergo sum': The African might say, 'I smell, I dance the other I am.' This does not mean that 'African' implies the rejection of any form of reason. Senghor argues that to be 'African' means to make use of another form of reason, namely 'reason-byembrace' (Senghor 1983:33).

The logic of reclaiming African subjectivity and reinterpreting African socio-cultural resources as representative ideals are expressed provocatively in the concept of négritude. Senghor and Aimé Césaire, the politician and poet from Martinique, played a major role in the initial development of this concept. Césaire, despite not being 'African' in a geographic sense of the word, was the first to make use of this concept, and does so in a polemical context. In the surrealist Notebook of a return to my native land (Cahier d'un retour au pays natal) Césaire ([1968] 1995), uses the word to denote what it is not:

my négritude is not a stone, its deafness hurled against the clamour of the day

my négritude is not an opaque spot of dead water over the dead eye of the earth

my négritude is neither a tower nor a cathedral

it reaches deep down into the red flesh of the soil

it reaches deep into the blazing flesh of the sky

it pierces opaque prostration with its straight patience. (p. 115)

In reflecting on the definition of négritude, Senghor draws on work by Césaire to define this reclamation of African subjectivity as 'the awareness, defence and development of African cultural values' (Senghor 1979:96) or, elsewhere, 'the sum total of the values of the civilisation of the African world' (Senghor 1979:99). The concept does not purport to capture all of the diversity implied by it, and is in this sense a 'true myth', namely 'the awareness by a particular social group or people of its own situation in the world, and the expression of it by means of the concrete image' (Senghor 1979:97). This reclamation can be described as the 'symbolic progression from subordination to independence, from alienation, through revolt, to self-affirmation' (Irele 2011:40).

In Césaire's work already it is clear that the act of reclamation in itself is not enough. That which is reclaimed has been degraded and needs to be reinterpreted - or properly interpreted. Césaire contrasts négritude with négraille, or negridom, and emphasises that his project is not simply one of uncritically reclaiming received terminology. In the Cahier he makes it clear that he is not reclaiming ' $n$ ] egridom with its smell of fried onion', which 'rediscovers the sour taste of freedom in its spilt blood'. Negridom, in contrast to négritude, is 'standing in the hold / standing in the cabins / standing on deck / standing in the wind / standing under the sun / standing in the blood' (Césaire [1968] 1995:131).

An interesting element of the initial reflection on négritude is the refusal to develop it as a historically static or culturally absolutist concept of Africa. Writing in 1959, Senghor makes clear that the intention is not to '[revive] the past so as to live on in an African museum.' It is much rather about 'animating this world, here and now, with the values that come from our past' (Senghor 1979:78). This concept of Africa is also not meant to be culturally absolutist. In one of his lectures Senghor recounts discussions with Césaire on how to reconcile their Marxist convictions with the notion of négritude. He then refers to both himself and Césaire as 'half-castes' and argues that cultural contact, borrowing and mixing is necessary in changing and stable 'external situations'. It enables better adaptation to any situation (Senghor 1979:75).

A concept of Africa as reclamation and reinterpretation resonates with the writing found in other regions of the continent too. Kwame Nkrumah, for example, emphasises the need for Africa to 'speak by using its own voice'. This needs to start with its historiography. According Nkrumah, the history of Africa 'needs to be written as the history of our society, not as the story of European adventures' (Nkrumah 1973:125). Only in this way can it become 'a map of the growing tragedy and final triumph of our society' in order to, eventually, 'guide and direct African action' (Nkrumah 1974:63). In a letter to a 'whites only' school in South Africa on the future of Africa, Julius Nyerere expressly rejects a racialised understanding of Africa that uncritically glorifies what is understood as African history. According to Nyerere, the challenges are neither to 'be ashamed of our own heritage' nor to 'put aside everything which is not "traditionally African" and live forever as though Europeans had never come into contact with us' (Nyerere 1966:116). Africa as an ideal does not mean a 'uniform Africa', as 'this word "Africans" can include all those who have made their home in the continent, black, brown, white' (Nyerere 1966:117).

I argue that this Africa as ideal has internal coherence as a fourth concept of Africa, and can be understood as the 
reclamation, reinterpretation of African socio-cultural resources as representative ideals. This concept of Africa can contribute to explaining the way in which, for example, ubuntu is regarded as 'African'. Ramose (2002:271), in his influential article, describes ubuntu as 'the wellspring flowing with African ontology and epistemology' and can be regarded as 'the basis of African philosophy'. African ontology, epistemology and in fact African philosophy seem to refer to more than simply ontologies, epistemologies and philosophies that originate from Africa. The assumption much rather seems that there is a single ontology, epistemology or philosophy that can be called African. The same goes for ubuntu: It is presented as not one of many, but as the basis of African philosophy.

This use of Africa in this regard cannot be explained adequately by any combination of the previous three concepts of Africa. It becomes even more difficult when one considers the socio-linguistic origins of the word ubuntu. It is an Nguni word, most often defined by means of the isiZulu phrase 'Umuntu ngumuntu ngabantu', or 'a person is a person through other persons.' Based on the available socio-linguistic evidence it can be argued linguistic variants of $u b u n t u$ can be found in other regions of Africa too, for example, in east Africa where the words 'umundu' in Kikuyu, 'umuntu' in Kimeru, 'bumuntu' in kiSukuma and kiHaya are found, as well as 'gimuntu' in kiKongo and giKwese, spoken in central Africa (cf. Kamwangamalu 1999).

However, despite its primary linguistic location in the family of Nguni languages of southern Africa and its presence in selected languages in east and central Africa, the concept of ubuntu still seems to exclude those parts of Africa where Bantu languages are not spoken, especially Africa north of the Sahara. It also - on such a reading seems to disregard the immense linguistic and cultural plurality of the more than 1000 million people who live in Africa. This challenge is compounded when one takes Metz's differentiated approach to ubuntu into account (Metz 2007). Ubuntu is nonetheless viewed as an African, or even the African, moral and philosophical principle. If one attempts to interpret such a statement in terms of, for example, a geographical understanding of Africa, one struggles to make sense of it. The way in which Ramose (2002) uses 'Africa' to qualify ubuntu becomes plausible when one views its use as the reclamation and (continuing) reinterpretation of an African cultural resource, and setting it as a representative ideal.

This also highlights the limitations of this concept of Africa. The dangers of exclusivity and essentialism loom large. This is the case despite prominent usages of 'Africa' as ideal that uses it as a dynamic and inclusive concept. Such a concept of Africa should therefore not be understood as the search for consensus, but - and here I agree with Gyekye (1995:211) - as 'the results of the reflective exertions of an African thinker' that gives 'analytical attention to the intellectual foundations of African culture and experience'. This will necessarily include disagreement on which resources to reclaim, how to interpret them and the extent to which they can constitute representative ideals.

\section{Going further}

In the sections above I hope to have shown that there is more than one concept of Africa, and that no concept of Africa is ethically neutral. When we refer to Africa as a place, we find ourselves confronted with a concept that has stabilised only relatively recently as a designator of the continent of Africa and only very recently became the self-description of persons who in fact live in Africa. For most of the lifetime of the term it was used as an external designation with very few points of connection to the self-perception of the people on the continent, their histories and institutions. I also hope to have shown that Africa as a condition has internal coherence and, together with Africa as a place, continues to give the concept of Africa internal coherence as a commodity. Lastly I hope to have shown that the self-conscious reclaiming and reinterpretation of African socio-cultural resources - often in a synecdochic way - make possible a fourth concept of Africa, namely Africa as ideal. But this concept of Africa is also not ethically neutral, as it might run the risk of becoming an essentialist or exclusivist concept of Africa.

As I intimated in the introductory section, I do not regard these as the only concepts of Africa. Also other internally coherent concepts of Africa could exist. Despite the impression that the four concepts that I proposed function independently, it seems plausible that whenever we use the word 'Africa' we make use of most of these concepts - and possibly other - to differing degrees. The challenge is to incorporate those elements of the four concepts of Africa that describe geographic, political, economic, historical and sociocultural elements shared by people on the continent of Africa in a constructive and authentic manner.

But is it possible to salvage and combine the positive elements of these concepts? Even though such a project goes beyond the scope of this article, I nonetheless point in the direction of one such a possibility: Africa as encounter. Is Africa not also to be conceived as a symbol for the encounter between ' $\mathrm{I}$ ' and the other; between imposed and indigenous institutions; between those who thrive and those who barely survive; between minorities and majorities; between different cultures and linguistic groups?

In his poem 'A salute to the third world', Césaire brilliantly and movingly points in the direction of such an understanding of Africa. He integrates the diversity of the people and groups of Africa, the enduring effects of its commodification, denigration and self-destruction with the challenge of becoming an authentic place of encounter. In conclusion I cite an excerpt from the poem:

\section{Look:}

Africa is no longer

a black heart scratched 
at by the diamond of misfortune:

our Africa is a hand free of the cestus,

it is a right hand, palm forward,

the fingers held tight;

it is a swollen hand

a-wounded-open-hand,

extended to

all hands, brown, yellow,

white, to all the wounded hands

in the world. (Césaire 1983:353)

\section{Acknowledgements}

I would like to thank Zorada Swart, Etienne de Villiers, Florence Nazare, Bernard Slippers and the two anonymous reviewers for helpful exchanges on the article. In addition, the author gratefully acknowledges funding by the Alexander von Humboldt Foundation that enabled the research that led to this article.

\section{Competing interests}

The author declares that he has no financial or personal relationships which may have inappropriately influenced him in writing this article.

\section{References}

Alesina, A., Easterly, W. \& Matuszeski, J., 2011, 'Artificial states', Journal of the European Economic Association 9(2), 246-277.

Berlin Conference on West Africa, 1885, 'General Act', viewed 27 October 2015, from http://africanhistory.about.com/od/eracolonialism/l/bl-BerlinAct1885.htm

Betz, R.L., 2007, The mapping of Africa: A Cartobibliography of printed maps of the African Continent to 1700 , Hes \& De Graaf, 't Goy-Houten.

Césaire, A. [1968] 1995, Notebook of a Return to my Native Land [Cahier d'un retour au pays natal], Bloodaxe Books, Newcastle.

Césaire, A., 1983, The collected poetry, transl. C. Eshleman \& A. Smith (eds.), University of California Press, Berkeley.

Casey, J., 2005, 'Holocene occupations of the forest and savanna', in A.B. Stahl (ed.) African archaeology, pp. 225-248, Blackwell, Malden.

Collins, R.O. \& Burns, J.M., 2007, A history of sub-Saharan Africa, Cambridge University Press, Cambridge.

Conklin, A.L., 1997, A mission to civilize: The Republican idea of empire in France and West Africa, 1895-1930, Stanford University Press, Stanford.

Currie, T.E., Meade, A., Guillon, M. \& Mace, R., 2013, 'Cultural phylogeography of the Bantu languages of sub-Saharan Africa', Proceedings of the Royal Society B, Biological Sciences, 280(20130695).

Curtin, P., Feierman, S., Thompson, L. \& Vansina, J., 1995, African history: From earliest times to independence, Pearson, London/New York.

Daniels, C., 1987, 'Africa', in J. Wacher (ed.), The Roman world, pp. 223-265, Routledge, London/New York.

Ehret, C., 2001, 'Bantu expansions: Re-envisioning a central problem of early African history', The International Journal of African Historical Studies 34(1), 5-41.
Englebert, P., Tarango, S. \& Carter, M., 2002, 'Dismemberment and suffocation: A contribution to the debate on African boundaries', Comparative Political Studies 35(10), 1093-1118.

Goodman, M., 1997, The Roman world: $44 B C-A D$ 180, Routledge, London \& New York.

Gyekye, K., 1995, An essay on African philosophical thought: The Akan conceptual scheme, rev. edn., Temple University Press, Philadelphia.

Herodotus, 1890, The histories of Herodotus, MacMillan \& Co., London/New York.

Hertslet, E., 1894, The map of Africa by treaty, vol. 1, Her Majesty's Stationary Office, London.

Huffman, T.N., 2000, 'Mapungubwe and the origins of the Zimbabwe culture', Goodwin Series, 8, 14-29.

Irele, F.A., 2011, The negritude moment: Explorations in Francophone African and Caribbean literature and thought, Africa World Press, Trenton.

Königk, G., 1938, Die Berliner Kongo-Konferenz 1884-1885: Ein Beitrag zur Kolonialpolitik Bismarcks, Essener Verlag Anstalt, Essen.

Kamwangamalu, N. M., 1999, 'Ubuntu in South Africa: A sociolinguistic perspective to a pan-African concept', Critical Arts 13(2), 24-41.

Le Glay, M., Voisin, J. \& Le Bohec, Y., 2005, A history of Rome, 4th edn., Blackwell, Oxford.

Lévy-Bruhl, L. [1926] 1985, How natives think, transl. L.A. Clare, Princeton University Press, Princeton.

Metz, T., 2007, 'Toward an African moral theory', The Journal of Political Philosophy 15(3), 321-341.

Morden, R., 1680, Geography rectified: or, A description of the world, R. Morden \& T. Cockerill, London.

Nkrumah, K., 1970, Africa must unite, Panaf, London.

Nkrumah, K., 1973, I speak of freedom, Panaf, London.

Nkrumah, K., 1974, Consciencism: Philosophy and ideology for de-colonisation, Panaf, London.

Nyerere, J.K., 1966, Freedom and unity: A selection from writings and speeches, 1952 1965, Oxford University Press, Dar es Salaam.

O'Brien, P., 1982, 'European economic development: The contribution of the periphery', Economic History Review 35(1), 1-18.

Pakenham, T., 2001, The scramble for Africa: 1876-1912, Phoenix Press, London.

Ramose, M.B., 2002, 'The philosophy of Ubuntu and Ubuntu as philosophy', in P.H. Coetzee \& A. P. J. Roux (eds.), The African philosophy reader, 2nd edn., pp. 270280, Routledge, London/New York.

Reid, R.J., 2009, A history of modern Africa: 1800 to the present, Wiley \& Blackwell, Malden/Oxford.

Ross, E.S., 2008, s.v. 'History of the name Africa', in J. Middleton \& J.C. Miller, New Encyclopedia of Africa, Scribner, Detroit, pp. 9-10.

Scullard, H.H., 1980, A history of the Roman World: 753 to 146 BC, 4th edn., Routledge, London/New York.

Senghor, L. S., 1979, Prose and poetry, transl. J. Reed, Heinemann, London.

Shaw, B.D., 2014, 'Who are you? Africa and Africans', in J. McInerney (ed.), WileyBlackwell Companion to ethnicity in the ancient Mediterranean, Wiley-Blackwell, pp. 527-540, Malden/Oxford.

Touré, S., 1963, Guinean revolution and social progress, S.O.P. Press, Cairo.

Tylor, E.B. [1871] 1920, Primitive cultures: Researchers into the development of mythology, philosophy, religion, language, art, and custom, John Murray, London.

Wesseling, H.L., 1996, Divide and rule: The partition of Africa, 1880-1914, transl. A. J. Pomerans, Praeger, London.

Wikipedia n.d., General-Akte der Berliner Konferenz (Kongokonferenz), viewed n.d. from http://de.wikisource.org/wiki/General-Akte der Berliner Konferenz \%28 Kongokonferenz $\% 29$

Worger, W. H., Clark, N. L. \& Alpers, E. A. (eds.), 2010, Africa and the West: A documentary history, vol. 1, Oxford University Press, Oxford.

Young, R. J.C., 2009, Postcolonialism: A historical introduction, Blackwell, Oxford. 